九州大学学術情報リポジトリ

Kyushu University Institutional Repository

\title{
Systematics of the Weevil Genus Gryporrhynchus Roelofs (Coleoptera, Curculionidae)
}

Kojima, Hiroaki

Entomological Laboratory, Faculty of Agriculture, Kyushu University

Morimoto, Katsura

Entomological Laboratory, Faculty of Agriculture, Kyushu University

https://doi.org/10.5109/24099

出版情報 : 九州大学大学院農学研究院紀要. 40 (1/2)，pp.117-134，1995-12. Kyushu University バージョン：

権利関係 : 


\title{
Systematics of the Weevil Genus Gryporrhynchus Roelofs (Coleoptera, Curculionidae) ${ }^{1,2)}$
}

\author{
Hiroaki Kojima and Katsura Morimoto \\ Entomological Laboratory, Faculty of Agriculture, \\ Kyushu University, Fukuoka, 812-81 Japan \\ (Received July 20,1995)
}

\begin{abstract}
Fourth part of our systematic study on the tribe Ochyromerini from East Asia treats the genus Gryporrhynchus Roelofs with descriptions of 10 new species as follows: Grypormynchus obscuroides sp. nov. (Taiwan), G.ryukyuensis sp. nov. (Japan), G. shigematsui sp. nov. (Japan), G. borneensis sp. nov. (E. Malaysia), G. bengalensis sp. nov. (Bangladesh), G. nepalensis sp. nov. (Nepal), G. rotundicollis sp. nov. (E. Malaysia), G. oripenmis sp. nov. (E. Malaysia), G. constricticeps sp. nov. (E. Malaysia) and G. senohi sp. nov. (Thailand). ' Redefinition of the genus, key to species, illustrations and photos of habitus and important features of each species are provided.
\end{abstract}

\section{INTRODUCTION}

The genus Gryporrhynchus was established by Roelofs (1875) for obscurus from Japan in the "tribus Eugnomides ?". Thence, it was enumerated in the subfamily Cossoninae by Winkler (1932) and Csiki (1936), and its systematic position was settled in the tribe Endaeini (=Ochyromerini) of the subfamily Tychiinae by Morimoto (1962). This genus contains only one species from Japan and Korea up to the present, but ten more species are found in our cabinets, which were collected from Japan, Thailand, Malaysia, Nepal and Bangladesh. Weevils of this genus are generally rare in the collections as those in the other genera of the tribe Ochyromerini because of the lack of information on the biology, small size and inconspicuous characters. They are usually captured sporadically on evergreen trees by beating or sweeping, and the host trees have been confirmed only on two species : Per-sea thunbergii for 0. shigematasui n. sp. and Mango tree for G. bengalensis $\mathrm{n}$. sp. Judging from our present knowledge, this genus may have wide range of distritbuiton in Asia and many species may acutally exist in the canopy of various trees.

In this paper, ten new species of the genus are described from the collection of Kyushu University taken by the following friends, to whom we wish to express our cordial thanks for their kind cooperation: the late Dr. K. Baba, Mr. K. Emoto, Mr. H. Kawase, Mr. I. Matoba, Dr. S. Miyakawa, Mr. Y. Miyatake, Mr. Y. Okushima, Dr. T. Senoh, and Mr. K. Shigematsu.

1) Study on the tribe Ochyromerini (Coleoptera, Curculionidae) from East Asia IV.

2) Contribution from the Entomological Laboratory, Faculty of Agriculture, Kyushu University, Fukuoka (Ser. 4, No. 100). 


\section{Genus Gryporrhynchus Roelofs}

Type species: Gryporrhychus obscurus Roelofs.

See Kojima \& Morimoto (1995c) for synonymy.

Owing to the increase of included species from one to eleven, the genus is newly defined as in the followings:

Redescription: Derm black or blackish, rarely dark brown, often partly lighter. Head usually without constriction, weakly concave before or above eyes on dorsum, often weakly concave or constricted behind eyes on dorsum in lateral aspect; forehead between eyes about as wide as or a little narrower than the base of rostrum. Eyes moderately convex from temples, not close to each other. Rostrum varies from stout to slender; antennal scrobes each with two dorsal carinae, upper dorsal carina sharp, directing to the lower part of eye, lower dorsal carina indistinct, directing to beneath eye, ventral carina running to beneath the base of rostrum; antennal scape retracted between lower dorsal and ventral carinae, and not touching eye. Antennae with scape as long as or longer than funicle; funicle six-segmented; club often large, longer than funicle, somewhat depressed and different in sharp according to the angle of view. Prothorax usually rounded laterally, often subparallel-sided or widest at the base; dorsum clothed with fine recumbent setae and subrecumbent stouter setae. Scutellum usually covered with lighter setae than those of other parts. Elytra usually parallel-sided at basal half, separately rounded at apex; each interval clothed with fine recumbent setae and one or a few rows of suberect or subrecumbent stouter setae. Pygidium broadly exposed, almost vertical, or exposed at apical part in female and often apical part of propygidium visible in male. Legs with front femora similar in size to the posteriors, denticulate, teeth of middle and hind pairs often a little greater than those of front pair; tibiae with unci in front and middle pairs, those of hind pair smaller, rarely with long spine in male or usually indefinite in female; claws widely divergent, each with a broad flat process or a moderately sharp tooth at the base. Prosternum with coxae located near the base. Venter with the posterior margin of second ventrite a little broadly curved caudad at sides rather than those of third and fourth ventrites. Seventh tergite with a pair of scrapers at the anterior margin for stridulatory organ. Metendosternite with a pair of anterior tendons arisen from the base of anterior arms. Aedeagus with median lobe symmetrical, setose at apex, freely articulated with long struts, internal sac with one to several sclerites; tegmen open dorsally.

Some species described by us (1995a) in the genus Endaenidius are a little different from the type-species of the genus and somewhat similar to Gryporrhynchus in having erect, or suberect setae on the pronotum and elytra, and partly exposed pygidium, but eyes are not widely separated. In Gryporrhynchus the derm is usually black or blackish, whereas yellowish or reddish brown to dark brown in Endaenidius. The type-species of Endaenidius has the eyes widely separated, but the pygidium is concealed. Both genera are distinguishable by the following key.

1(2): Derm yellowish brown or reddish brown, rarely dark brown. Elytra conjointly rounded at apex, pygidium rarely exposed. Forehead between eyes narrower than base of rostrum, often very narrow and linear. Antennae with scape touching or very close to eye in most species when rested in scrobe 
2(1): Derm black or blackish. Elytra separately rounded at apex, pygidium broadly exposed and almost, vertical. Forehead between eyes about as wide as base of rostrum. Antennal scape not touching eye and running to beneath rostrum

Gryporrhynchus Roelofs

This genus is also closely related to Imerodes Marshall as stated by Kojima \& Morimoto (199513) in having the following common features: forehead between eyes almost as wide as base of rostrum; antennal scape not touching eye; antennal funicle sixsegmented; front coxae located near base of pronotum and metendosternite with each anterior tendon arisen from base of anterior arm. But this is easily separable from the latter by hairy derm, more or less dentate femora, setose penis at apex and open tegmen dorsally.

Key to species of the genus Gryporrhynchus

1(16): Head not constricted behind eyes, but usually weakly concave a little before or above eyes in lateral aspect

2(3): Body broadly ovate. Femora with a triangular tooth, which of middle and hind pairs a little greater than that of front pair. Body larger, $3.5 \mathrm{~mm}$ in length

3(2): Body ovate or oblong ovate. Body less than $3.0 \mathrm{~mm}$ in length

4(5): Femora with a triangular tooth. Antennal club large, longer than funicle

bengalensis sp. nov.

5(4): Femora with a small sharp or an indefinite tooth

6(7): Prothorax subparallel-sided at basal half. Front, femora with an indefinite tooth

7(6): Prothorax rounded laterally

nepalensis sp. nov.

8(11): Rostrum stout, shorter than pronotum in both sexes. Elytra with a row of suberect stouter setae on each interval

9(10): Body robuster. Prothorax widest at; the middle. Elytra triangularly produced anteriorly as usual at the conjoint base of 5-7 intervals; each interval with suberect setae shorter than width of an interval. Femora each with a minute tooth. Claws each with a moderately broad basal process

obscurus Roelofs

10(9): Body thinner. Prothorax widest a little behind the middle. Elytra triangularly and distinctly produced anteriorly at the conjoint base of 5-7 intervals; each interval with long suberect setae as long as width of an interval. Femora each with an indefinite tooth. Claws each with a sharp basal process

obscuroides sp. nov.

11(8): Rostrum longer than pronotum at least in female. Elytra with one or two rows of subrecumbent stouter setae on each interval

12(13): Blackish. Rostrum much longer than pronotum and setose on ventral surface in female $\ldots \ldots \ldots \ldots \ldots \ldots \ldots \ldots \ldots \ldots \ldots \ldots \ldots \ldots$ shigematsui sp. nov.

13(12): Rostrum a little longer than pronotum

14(15): Derm dark brown with yellowish brown setae. Antennal club shorter than 
funicle. Elytra with two, partly one rows of yellowish brown stouter setae on each interval .....................................................ryukyuensis sp. nov.

15(14): Derm blackish with silvery setae. Antennal club longer than funicle. Elytra with a row of dark stouter setae on each interval .................... bormeensis sp. nov.

16(1): Head weakly constricted or weakly concave behind eyes in lateral aspect

17(20): Head weakly constricted behind eyes

18(19): Prothorax widest at base. Hind tibiae each with a long spine-like uncus in male. Mesosternal process protruded, as high as middle coxae

constricticeps sp. nov.

19(18): Prothorax widest behind the middle. Hind tibiae each with a small uncus. Mesosternal process not protruded ........................................ senohi sp. nov.

20(17): Head weakly concave behind eyes. Prothorax widest at base. Elytra broadly ovate

ovipennis sp. nov.

\section{Gryporrhynchus obscurus Roelofs}

Gryporrhynchus obscurus Roelofs, 1875, Ann. Soc. ent. Belg., 18: 189.

See Kojima \& Morimoto (1995c) for detail.

Distribution: Japan (Honshu, Shikoku, Kyushu, Ryukyus), Korea (Cheju-do).

\section{Gryporrhynchus obscuroides sp. nov.}

(Fig. 1)

Male and female. Body oblong ovate. Derm black, legs dark brown to blackish, antennal scape and funicle, unci of tibiae and tarsi brownish.

Head without constriction; forehead between eyes nearly as wide as base of rostrum. Eyes weakly convex from temples. Rostrum robust, slightly (male) or evenly (female) curved, shorter than pronotum (2:3 in male or $4: 5$ in female), confluently punctured, with a shiny median carina, which is widening to apex and two rows of carinae on each side behind antennal insertions, sparsely and finely punctured, and shiny before antennal insertions; antennal scrobes running to lower parts of eyes. Antennae inserted a little (male) or just a little (female) before middle of rostrum; scape nearly as long as funicle; funicle with first segment $5 / 3$ times as long as second, third to sixth subequal in length, $2 / 3$ times as long as second; club as long as basal four segments of funicle combined.

Prothorax 1.20-1.25 times as wide as long, widest a little behind the middle, rounded laterally, slightly constricted at apex; dorsum with fine punctures mixed with a little larger ones irregularly, each fine puncture with a pale recumbent seta and a little larger one with a subrecumbet dark stouter seta. Scutellum rounded, densely covered with recumbent whitish setae. Elytra 1.5-1.6 times as long as wide, parallel-sided at basal half, concave at base of fourth interval and triangularly produced anteriorly at conjoint base of fifth to seventh intervals; each interval clothed with fine recumbent pale setae and medially with a row of suberect longer, stouter dark setae. Pygidium completely exposed and vertical in male, or apex often exposed in female. Legs clothed with pale recumbent 


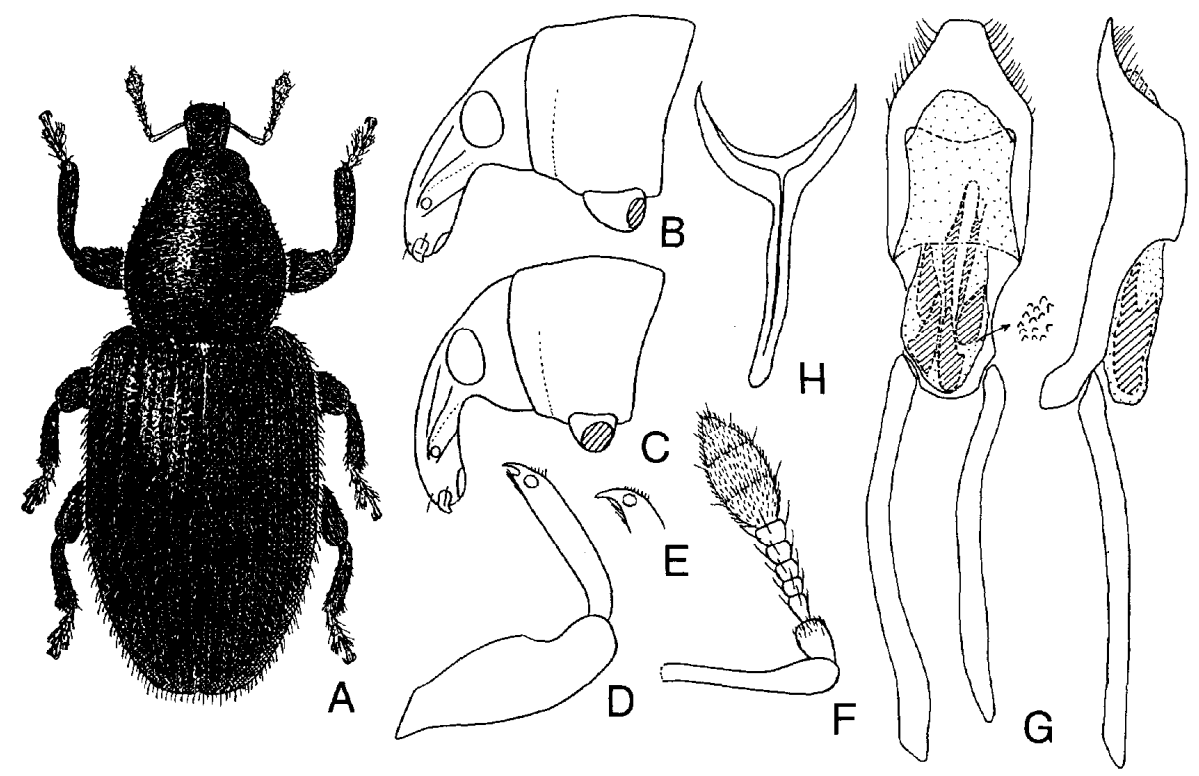

Fig. 1. Gryporrhynchus obscuroides sp. nov. A: Female. B: Head and prothorax, lateral, male. C: Ditto, female. D: Front leg, female. E: Ditto, apical part of tibia, male. F: Antenna. G: Penis. H: Tegmen.

setae; femora with an indefinite tooth; front and middle tibiae sexually dimorphic at apical parts, broadly uncinate in male, or pointed at inner angle and uncinate from outer angle in female; claws moderately long and sharply toothed.

Prosternum with the distance between coxae and submarginal sulcus as great as that between this sulcus and anterior margin. Venter with first and second ventrites flattened in the middle in male.

Aedeagus with penis with a long and two pairs of short sclerites in inner sac.

Length: 2.4-2.5 $\mathrm{mm}$.

Holotype: male (Type No. 3005, Kyushu Univ.), Nanshanchi, Taiwan, 16. iv. 1975. S. Imasaka leg.

Paratypes: 1 male, Wushe, Taiwan, 27. v. 1975. S. Imasaka leg. 1 male, Tsai Tie Ku, near Liu Kui, S-Taiwan, 6. x. 1986, K. Baba leg. 1 female, Tai Yuan Shan, near Liu Kui, STaiwan, 1. vi. 1986. K. Baba leg. 1 male, Wushe 1250 m, Nantou Hsien, C. Taiwan, 30. viii2. ix. 1982, L.Y. Chou \& K. C. Chou leg. (preserved in Taiwan Agricultural Research Institute, Taichung). 1 female, Nanshanchi, Nantou Hsien, 20-23. iii. 1995, H. Kojima \& M. Suehiro leg. 1 male, near Liu Kui, Kaohsiung Hs. Taiwan, 5-9. iv. 1995, H. Kojima leg.; 1 female, H. Goto leg.

Distribution: Taiwan (Central and southern parts).

Remarks: This is very close to G. obscurus Roelofs from Japan and Korea, but the body is thinner. 


\section{Gryporrhynchus ryukyuensis sp. nov.}

(Figs. 2A, 3)

Male and female. Derm dark brown, head and rostrum darker, often blackish, antennae and legs light reddish brown.

Head without constriction; forehead between eyes nearly as wide as base of rostrum, with a few scale-like setae along eyes. Eyes weakly convex from temples. Rostrum slightly curved, as ldng as (male) or a little longer than (7:6, female) pronotum, shiny before antennal insertions in female, with a median and two rows of lateral carinae on each side behind antennal insertions, of which median one is indefinite in female; antennal scrobe running to lower part of eye. Antennae inserted a little before middle (male) or at middle (female) of rostrum; scape a little longer than funicle (7:6); funicle with first segment $5 / 3$ times as long as second, third to sixth subequal in length, 2/3 times as long as second; club as long as basal four segments of funicle combined.

Prothorax 1.4 times as wide as long, widest at basal one-third, strongly rounded laterally, weakly constricted at apex; dorsum with fine punctures mixed with larger ones, each fine puncture with a fine recumbent pale setae and larger one with a subrecumbent yellowish brown stouter setae. Scutellum a little longer than wide, densely covered with recumbent pale setae. Elytra ovate, 1.2-1.3 times as long as wide, subparallel-sided at basal half; each interval densely clothed with recumbent pale setae and with one, partly two rows of subrecumbent yellowish brown stouter setae. Pygidium exposed, vertical, densely clothed with setae as on elytra, propygidium visible at posterior part in male. Legs clothed with recumbent pale setae; femora with a minute tooth; tibiae slightly widening toward apex; claws each with a broad flat basal process.

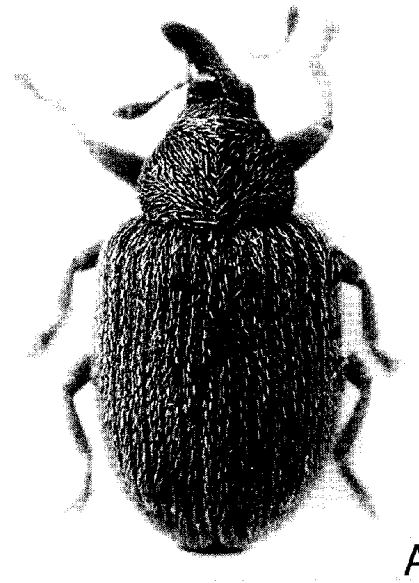

A

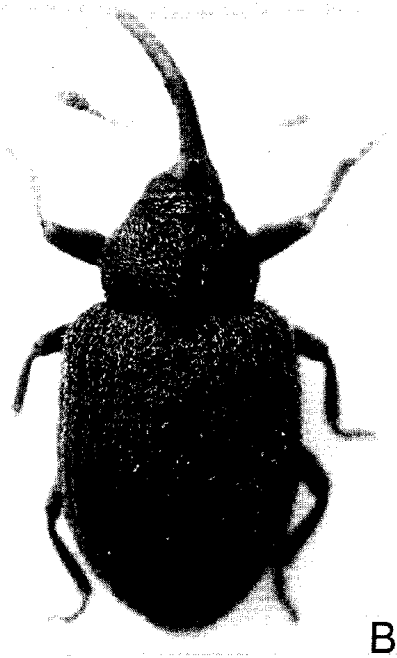

Fig. 2. Gryporrhynchus spp.

A: ryukyuensis sp. nov. B: shigematsuisp. nov. 


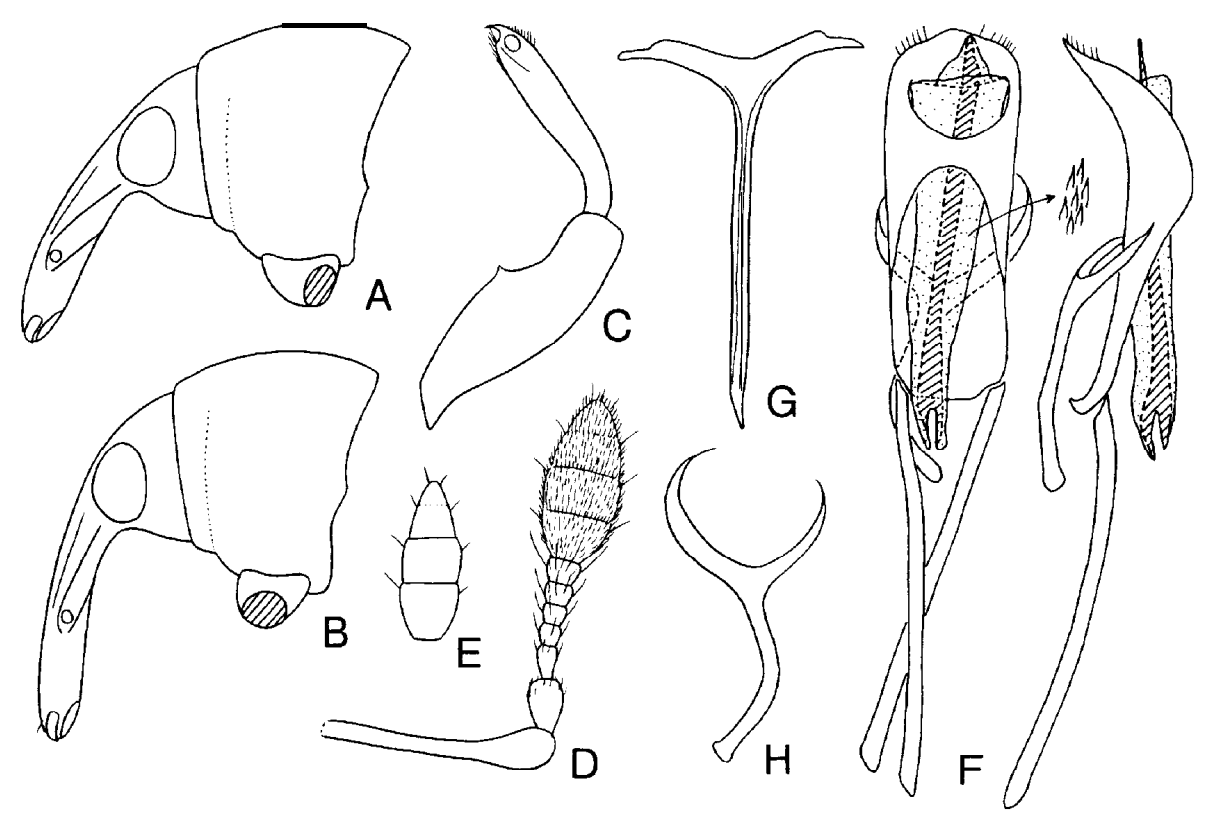

Fig. 3. Gryporrhynchusryukyuensis sp. nov. A: Head and prothotax, lateral, male. B: Ditto, female. C: Front leg. D: Antenna. E: Ditto, club, lateral. F: Penis. G: Spiculum gastrale. $\mathrm{H}$ : Tegmen.

Prosternum with distance between coxae and submarginal sulcus as great as that between this sulcus and anterior margin. Venter with first and second ventrites flattened in the middle in male.

Aedeagus with penis with a slender sclerite in inner sac.

Length: $2.4 \mathrm{~mm}$.

Holotype: male (Type No. 3006, Kyushu Univ.), Mt. Omotodake, Ishigaki Is., Ryukyus, 15. iii. 1990, Y. Okushima leg.

Paratypes: 1 female, Inaba, Iriomote, Ryukyus, 10. iii. 1964, Y. Miyatake leg. 1 male, Mt. Bannadake, Ishigaki Is., Ryukyus, 29. vi. 1993, H. Kojima leg. 1 male, Nakamagawarindo, Iriomote Is., 27. iii. 1990, H. Kojima leg.

Distribution: Japan (Ryukyus: Ishigaki-jima and Iriomote-jima Isls.).

Remarks: This is closely related to G. shigemutsui sp. nov. from Japan (Honshu) and G. bomzeensis sp. nov. from East Malaysia (Sabah), but separable from the former by the coloration and the length of rostrum and from the latter by the length ratio of antennal funicle to club.

This is rarely collected by beating and sweeping on the Yaeyama groups of the Ryukyus in spite of repeated collecting trips by many entomologists. 


\section{Grgporrhgnchus shigematsui sp. nov.}

(Figs. 2B, 4A-C)

Female. Derm blackish, antennae and legs brownish to dark brown.

Head without constriction; forehead between eyes a little narrower than base of rostrum. Eyes slightly convex from temples. Rostrum slender, weakly curved, much longer than pronotum $(5: 3)$, faintly narrowed to antennal insertions, slightly widened at this point, thence weakly widening to apex, confluently punctured, with five rows of carinae behind antennal insertions, shiny and sparsely punctured before antenna1 insertion; venter setose medially; antennal scrobe running to lower part of eye. Antennae inserted at middle of rostrum; scape longer than funicle (10:7); funicle with first segment 5/3 times as long as second, third to sixth subequal in length, 2/3 times as long as second; club as long as basal four segments of funicle combined.

Prothorax 1.25-1.30 times as wide as long, widest a little behind the middle, rounded laterally, slightly constricted at apex; dorsum with mixed larger and fine punctures, each larger puncture with a subrecumbent dark stouter setae and each fine one with a fine recumbent pale setae. Scutellum a little longer than wide, clothed with recumbent whitish setae. Elytra about 1.3 times as long as wide, subparallel-sided at basal half; each interval clothed densely with fine recumbent pale setae and with one or two rows of subrecumbent darker stouter setae. Pygidium exposed, nearly vertical, densely clothed with pale setae. Legs clothed with recumbent pale setae; femora with a small sharp tooth; tibiae slightly widening toward apex; claws each with a broad flat basal process.

Prosternum with distance between coxa and submarginal sulcus as great as that between this sulcus and anterior margin.

Male. Unknown.

Length: 2.4-2.5 $\mathrm{mm}$.

Holotype: female (Type No. 3007, Kyushu Univ.), Tategasaki, Kumano-shi, Mie Pref., 3. v. 1994, K. Shigematsu leg.

Paratypes: 2 females, same locality as holotype, 8. xi. 1990, H. Kawase leg.; 1 female, 3. xii. 1991, H. Kawase leg. 1 female, Iwabuchi, Hirogawa-cho, Wakayama Pref., 4. v. 1984, I. Matoba leg.

Distribution: Japan (Honshu: Kii Peninsula).

Remarks: This is similar to the species of Acalyptus in having slender rostrum and exposed pygidium, but structure of the venter is different. This is closest to G. ryukyuensis sp. nov. except for the slenderer rostrum and blackish coloration.

Mr. Kazumi Shigematsu collected some specimens on Persea thunbergii (Tabunoki in Japanese), to whom the name of species is dedicated.

\section{Grgporrhynchus borneensis sp. nov.}

(Figs. 4D-F, 5A)

Female. Derm black, antennae and legs reddish brown.

Head without constriction; forehead between eyes a little narrower than base of rostrum. Eyes faintly convex from temples. Rostrum a little longer than pronotum, 


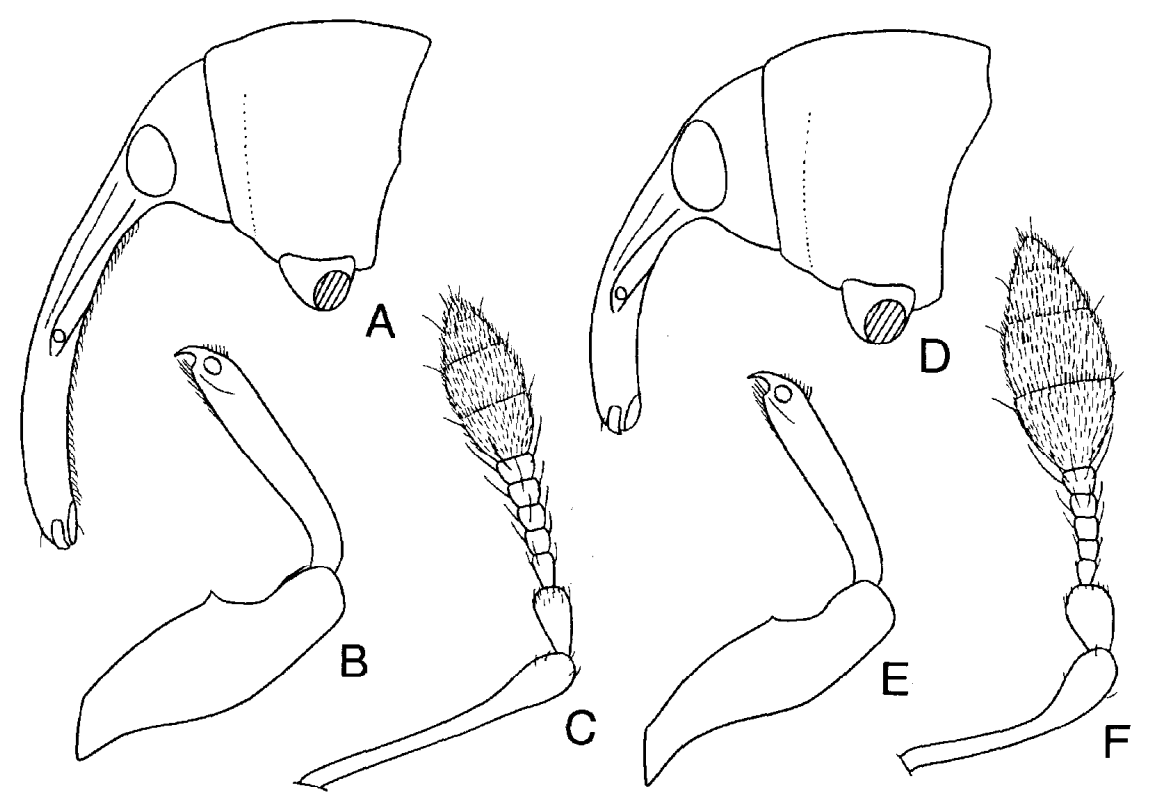

Fig. 4. A-C: Gryporrynchus shigematsui sp. nov., female. D-F: G. borneensis sp. nov., female. A, D: Head and prothorax, lateral. B, F: Front leg. C, G: Antenna.

confluently punctured and two rows of carinae on each side behind antennal insertions, scarcely punctured at apical half; antennal scrobe running to lower part of eye. Antennae inserted at middle of rostrum; scape a little longer than funicle $(4: 3)$, curved near apex; funicle with first segment more than twice as long as second, third to fifth subequal in length, a little longer than second, sixth a little longer than fifth; club large, as long as scape .

Prothorax 1.4 times as wide as long, widest a little behind the middle, weakly rounded laterally, slightly constricted at apex; dorsum densely and finely punctured, clothed with recumbent silvery setae and a little stouter dark setae. Scutellum rounded, as long as wide, clothed with recumbent silvery setae. Elytra ovate, 1.25 times as long as wide, subparallel-sided at basal half; each interval densely clothed with fine recumbent silvery setae and medially with a row of subrecumbent stouter, longer dark setae. Pygidium exposed, nearly vertical, densely clothed with pale setae at apical part. Legs clothed with recumbent pale setae; each femur with a minute tooth; tibiae slightly widening toward apex; claws each with a broad flat basal process.

Prosternum with distance between coxa and submarginal sulcus as great as that between this sulcus and anterior margin.

Male. Unknown.

Length: $2.2 \mathrm{~mm}$.

Holotype: female (Type No. 3008, Kyushu Univ.), Mt. Kinabalu (nr. Head-quarters), Sabah, E. Malaysia, 18-21. viii. 1981, K. Morimoto leg.

Distribution: E. Malaysia (Sabah) . 
Remarks: This is similar to G. ryukyuensis sp. nov., but easily separable from it by the elytra with a row of subrecumbent setae on each interval, and also related to $\mathrm{G}$. bengalensis sp. nov., but easily separable from it by the characters noted in the key.

\section{Grgporrhynchus bengalensis sp. nov.}

(Figs. 5B, 6)

Male and female. Derm blackish, antennae and legs reddish brown, often dark reddish brown.

Head without constriction; forehead between eyes nearly as wide as base of rostrum. Eyes faintly convex from temples. Rostrum evenly curved, a little shorter than (male) or as long as (female) pronotum, confluently punctured and two rows of carinae on each side behind antennal insertions, median carina visible near the base, widening and become indefinite toward apex, puncturs becoming sparse before antennal insertions; antennal scrobe running to lower part of eye. Antennae inserted before middle (male) or just a little before middle (female) of rostrum; scape longer than funicle (5:3); funicle with first segment thrice as long as second, third to fifth subequal in length, 2/3 times as long as second, sixth a little longer than fifth; club large, a little shorter than scape.

Prothorax 1.3-1.4 times as wide as long, widest a little behind the middle, weakly rounded laterally, slightly constricted at apex; dorsum strongly punctured, punctures becoming smaller near anterior margin, clothed with recumbent dark brownish setae and subrecumbent dark stouter setae. Scutellum longer than wide, clothed with recumbent greyish setae. Elytra 1.20-1.25 times as long as wide, subparallel-sided at basal half; each interval clothed with recumbent dark brownish setae and medially with a row of

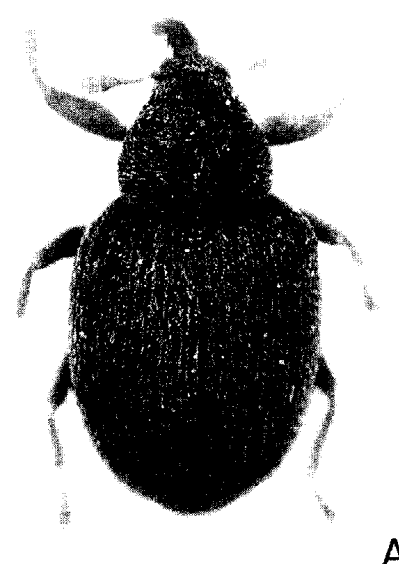

A

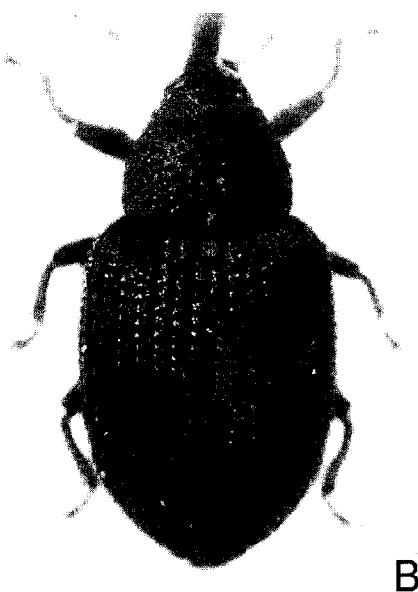

Fig. 5. Gryporrhynchus spp A: borneensis sp. nov. B: bengalensis sp. nov. 
subrecumbent stouter, longer dark setae. Pygidium exposed, nearly vertical, densely clothed with dark stouter setae at apex, propygidium visible at apex in male. Legs clothed with pale recumbent setae; femora with a triangular tooth; tibiae widening internally a little before the middle, apical part with sexual dimorphism, pointed at inner angle and uncinate from outer angle in female or uncinate from inner angle in male; claws each with a broad flat basal process.

Prosternum with distance between coxa and submarginal sulcus as great as that between this sulcus and anterior margin. Venter with first ventrite flattened in the middle in male.

Length: $1.9-2.5 \mathrm{~mm}$.

Holotype: female (Type No. 3009, Kyushu Univ.), IPSA, Salna, Gazipur, Bangladesh, 17-25. x. 1994, K. Morimoto leg. (on Mango).

Paratypes: 9 males and 5 females, same data as holotype.

Distribution: Bangladesh.

Remarks: This is closely related to G. borneensis sp. nov. in having large club of antenna, but easily separable from it by the larger triangular tooth on the femora.

All the specimens were captured on young leaves of Mango tree by sweeping in the campus of the Institute of Postgraduate Studies in Agriculture, Bangladesh.

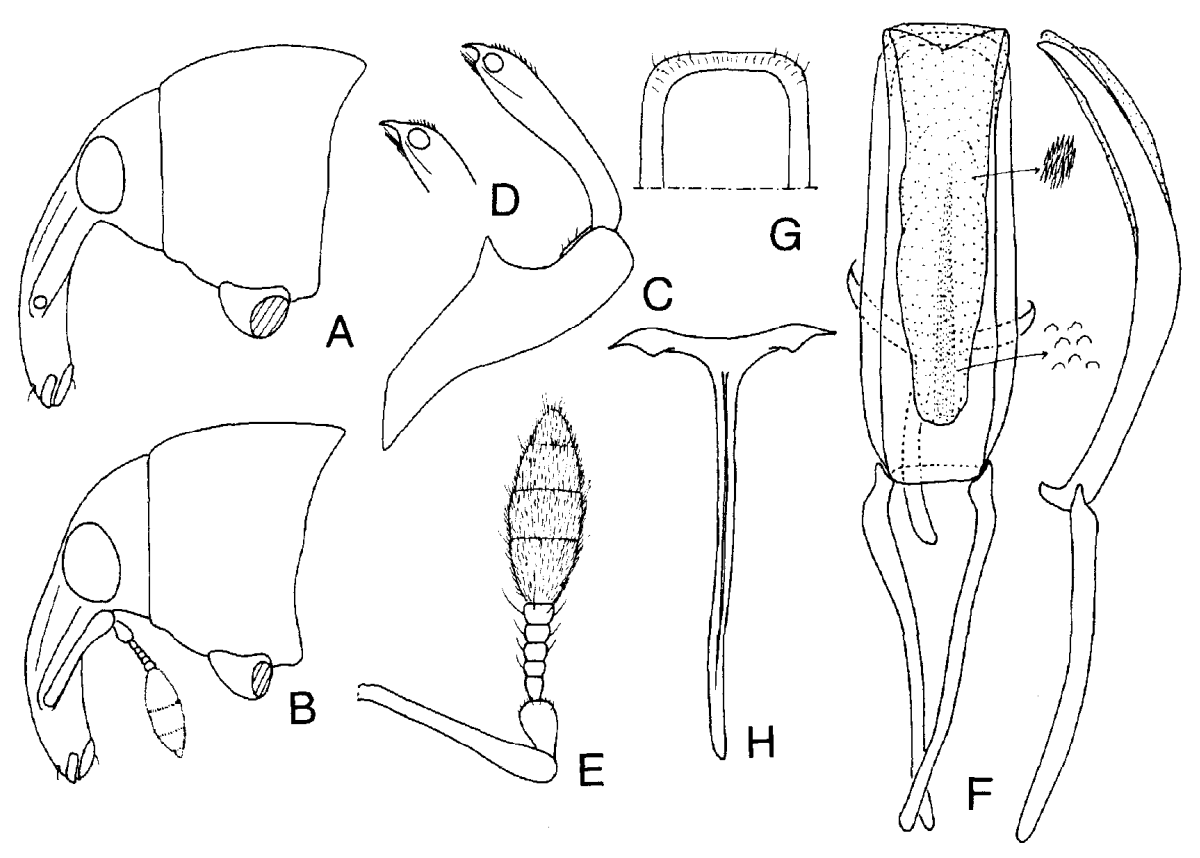

Fig. 6. Gryporrhynchus bengalensis sp. nov. A: Head and prothorax, lateral, male. B: Ditto, female. C: Front leg, female. D: Ditto, apical part of tibia, male. E: Antenna. F: Penis. G: Ditto, apical part. H: Spiculum gastrale. 


\section{Gryporrhynchus nepalensis sp. nov.}

(Fig. 7)

Male. Derm blackish, antennae, tibiae and tarsi, often femora dark brown.

Head without constriction; forehead between eyes nearly as wide as base of rostrum. Eyes faintly convex from temples. Rostrum as long as pronotum, confluently punctured, with five rows of carinae behind antennal insertions; antennal scrobe running to lower part of eye. Antennae inserted a little before the middle; scape as long as funicle; funicle with first segment twice as long as second, third to sixth subequal in length; club nearly as long as basal four segments of funicle combined.

Prothorax 1.35-1.40 times as wide as long, subparallel-sided at basal half, then narrowing toward apex, faintly constricted at apex; dorsum with moderately strong punctures, clothed with recumbent pale setae and subrecumbent greyish brown stouter setae. Scutellum much longer than wide, densely covered with whitish setae. Elytra 1.35-1.40 times as long as wide, parallel-sided at basal half; each interval densely clothed with fine recumbent pale setae and medially with a row of subrecumbent greyish brown stouter setae. Pygidium exposed, nearly vertical, densely clothed with greyish brown setae at apex. Legs clothed with recumbent pale setae; femora with an indefinite tooth; tibiae slightly widening toward apex; claws each with a broad flat basal process.

Prosternum with distance between coxa and submarginal sulcus a little greater than that between this sulcus and anterior margin. Venter with first and second ventrites weakly depressed in the middle.

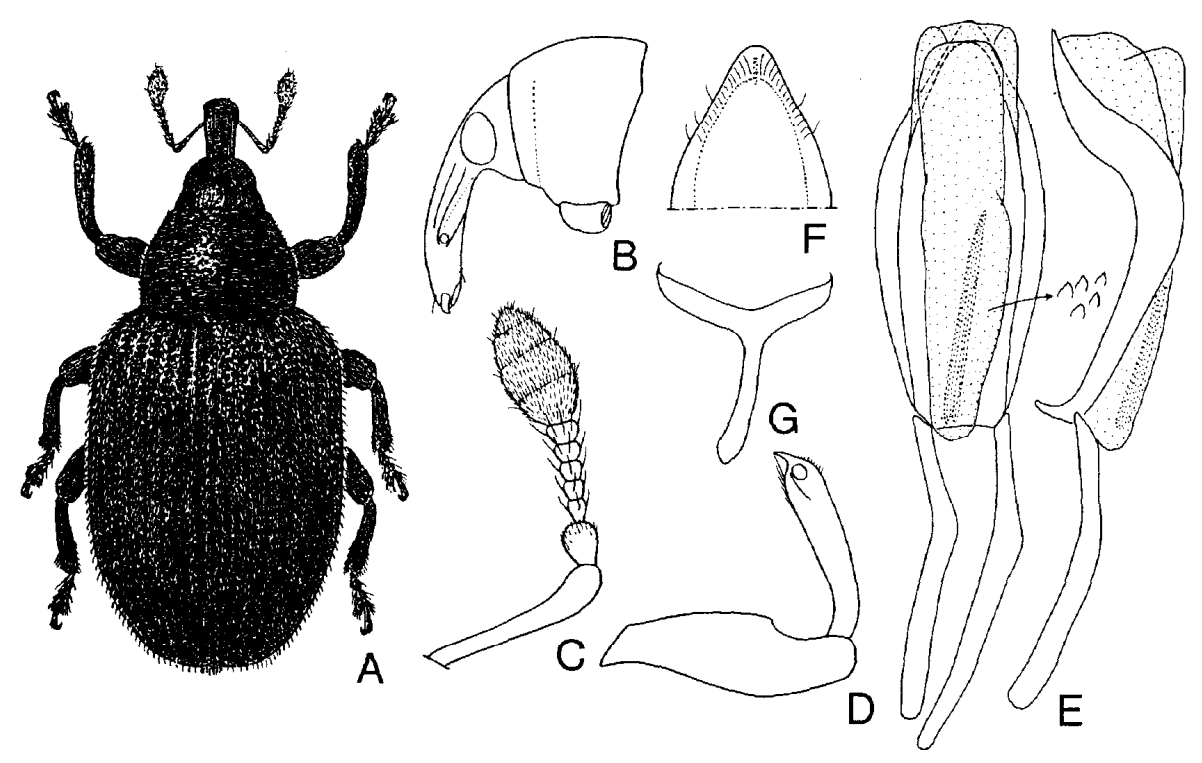

Fig. 7. Gryporrhynchus nepalensis sp. nov. A: Male. B: Head and prothorax, lateral, male. C: Antenna. D: Front leg. E: Penis. F: Ditto, apical part. G: Tegmen. 
Female. Unknown.

Length: 2.1-2.3 $\mathrm{mm}$.

Holotype: male (Type No. 3010, Kyushu Univ.), Basantapur (2300 m), Nepal, 10. v. 1972. (Malaise trap).

Paratypes: 2 males, same data as holotype (1 male, Y. Nishida leg).

Distribution: Nepal.

Remark This is similar to G. ryukyuensis sp. nov., G. shigematsui sp. nov. and G. bormeensis sp. nov., but easily separable from them by the indefinite tooth of femora and subparallel-sided pronotum at basal half.

Two specimens were caught in the Malaise trap.

\section{Gryporrhynchus rotundicollis sp. nov.}

(Figs. 8A, 9A-C)

Male. Derm black, antennae, unci of tibiae and tarsi brownish to dark brown.

Head without constriction, forehead between eyes a little narrower than base of rostrum. Eyes faintly convex from temples. Rostrum just a little shorter than pronotum, confluently punctured, with five rows of carinae behind antennal insertions, shiny and finely punctured at apical part; antennal scrobe running to lower part of eye. Antennae inserted a little before middle of rostrum; scape longer than funicle $(3: 2)$; funicle with first segment $5 / 3$ times as long as second, third to sixth subequal in length, a little shorter than second; club a little longer than funicle (10:9).

Prothorax 1.3 times as wide as long, widest a little behind the middle, strongly rounded laterally, weakly constricted at apex; dorsum densely and finely punctured, clothed with fine recumbent dark brownish setae and subrecumbent dark stouter setae.
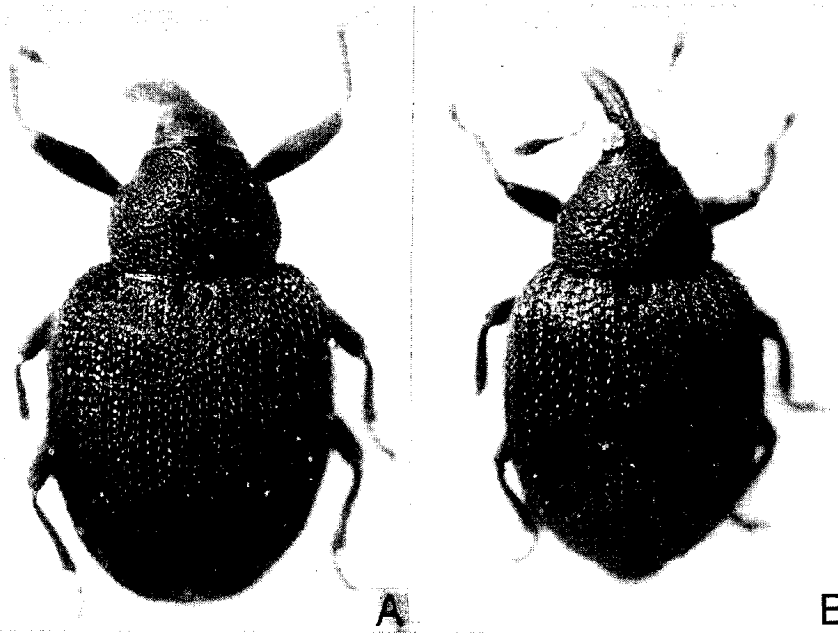

Fig. 8. Gryporrhynchus spp. A: rotundicollis sp. nov. B: ovipennis sp. nov. 
Scutellum a little longer than wide, densely covered with pale setae. Elytra broadly ovate, 1.14 times as long as wide, subparallel-sided at basal half; each interval clothed with fine recumbent dark brownish setae and a few rows of subrecumbent dark stouter setae. Pygidium exposed, nearly vertical, densely clothed with dark setae. Legs clothed with recumbent pale setae; femora with a small triangular tooth, which of middle and hind pairs a little larger than that of fore pair; tibiae slightly widening to apex; claws each with a little long basal process.

Prosternum with distance between coxa and submarginal sulcus a little greater than that between this sulcus and anterior margin. Metasternal process as high as level of middle coxae, weakly bituberculate. Ventet with first and second ventrites depressed in the middle.

Female. Unknown.

Length: $3.5 \mathrm{~mm}$.

Holotype: male (Type No. 3011, Kyushu Univ.), 10.5 miles point from Keningau (Kimanis road), Sabah, Borneo Is., E. Malaysia, 6-10. iii. 1993, H. Kojima leg.

Distribution: E. Malaysia (Sabah).

Remarks: This is the largest species in this genus and related to preceding four new species, but easily separable from them by the large and broadly ovate body.

\section{Gryporrhynchus ovipennis sp. nov.}

(Figs. 8B, 9D-G)

Female. Derm black, antenna1 club and funicle, and legs dark brown, antenna1 scape, unci of tibiae and tarsi brownish.

Head weakly concave behind eyes on dorsum; forehead between eyes $3 / 5$ times as wide as base of rostrum. Eyes weakly convex from temples. Rostrum just a little shorter than pronotum, confluently punctured, with five rows of carinae behind antennal insertions, shiny and sparsely punctured at apical half; antennal scrobe running to beneath eye. Antennae inserted just a little before middle of rostrum; scape a little longer than funicle; funicle with first segment twice as long as second, third to fifth subequal in length, a little shorter than second, sixth a little longer than fifth, as long as second; club as long as basal five segments of funicle combined.

Prothorax 1.45 times as wide as long, widest at base, thence weakly curved and narrowing toward apex, slightly constricted at apex; dorsum clothed with fine recumbent pale setae, strongly punctured, punctures becoming smaller near anterior margin, each puncture with a subrecumbent dark stouter seta. Scutellum longer than wide, clothed with setae. Elytra broadly ovate, 1.07 times as long as wide, subparallel-sided at basal half; each interval clothed densely with fine recumbent pale setae and medially with one, partly two rows of subrecumbent dark stouter setae. Pygidium exposed, nearly vertical, clothed with dark setae at apical part. Legs clothed with recumbent pale setae; femora with a sharp, small triangular tooth, which of middle and hind pairs a little greater than that of front pair; tibiae slightly widening to apex; claws each with a broad flat basal process.

Prosternum with distance between coxa and submarginal sulcus greater than that 


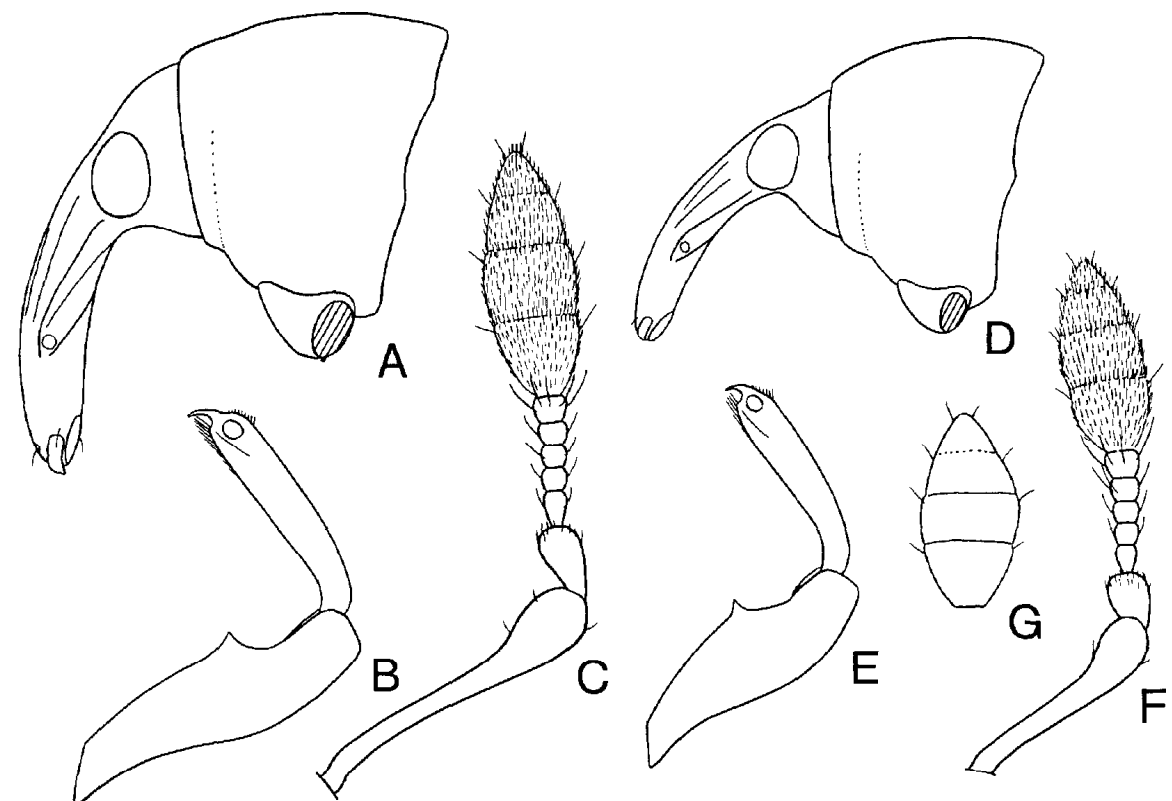

Fig. 9. A-C: Gryporrhynchus rotundicollis sp. nov. D-F. Gryporrhynchus ovipennis sp. nov. A, D: Head and prothorax, lateral. B, E: Front leg. C, F: Antenna. G: Ditto, lateral.

between this sulcus and anterior margin.

Male. Unknown.

Length: 2.2.mm.

Holotype: female (Type No. 3012, Kyushu Univ.), Mananam, $50 \mathrm{~km} \mathrm{SW}$ of Telupid, Sabah, E. Malaysia, 5-9. viii. 1981, K. Morimoto leg.

Distribution: E. Malaysia (Sabah).

Remarks: This is similar to G. rotundicollis sp. nov. in having broadly ovate body, but the head is concaved behind the eyes on dorsum, and closely related to the following two new species having weak constriction behind the eyes.

\section{Gryporrhynchus constricticeps sp. nov.}

(Figs. 10B, 11A-D)

Male. Derm black, antennae and tarsi dark brown, unci of tibiae and tarsal claws brownish.

Head weakly constricted behind eyes; forehead between eyes $3 / 5$ times as wide as base of rostrum. Eyes weakly convex from temples. Rostrum as long as pronotum, confluently punctured, with five rows of carinae behind antennal insertions, punctures becoming sparser before antennal insertions; antennal scrobe running to lower part of eye, extending to apical one-fourth before antennal insertions. Antennae inserted at middle of rostrum; scape longer than funicle $(3: 2)$, funicle with first segment more than 
twice as long as second, third and fourth subequal in length, a little longer than second, fifth and sixth subequal in length, a little longer than fourth; club as long as funicle.

Prothorax 1.3 times as wide as long, widest at base, narrowing to apex in a weak curve, weakly constricted at apex; dorsum clothed with fine recumbent dark setae, strongly punctured, punctures becoming smaller near anterior margin, each puncture with a subrecumbent dark stouter seta. Scutellum much longer than wide, clothed with whitish setae. Elytra 1.16 times as long as wide, subparallel-sided at basal half; each interval clothed with fine recumbent dark setae, and medially with one or two rows of subrecumbent dark stouter setae. Pygidium exposed, nearly vertical, clothed with dark setae. Legs clothed with recumbent pale setae; each femur with a triangular tooth, which of middle and hind pairs a little greater than that of front pair, with a few row of short erect setae beyond tooth; tibiae slightly widening to apex, hind tibia with a long spine-like uncus; claws each with a broad flat basal process.

Prosternum with distance between coxa and submarginal sulcus as great as that between this sulcus and anterior margin. Mesosternal process as high as the level of meddle coxae. Venter with first and second ventrites depressed in the middle.

Female. Unknown.

Length: $2.9 \mathrm{~mm}$.

Holotype: male (Type No. 3013, Kyushu Univ.), Mamut, Sabah, E. Malaysia, 11-14. viii. 1981, K. Morimoto leg.

Distribution: E. Malaysia (Sabah).

Remarks: This is characteristic among congeners by having the weakly constricted head behind the eyes and long spine-like uncus of the hind tibiae in male.

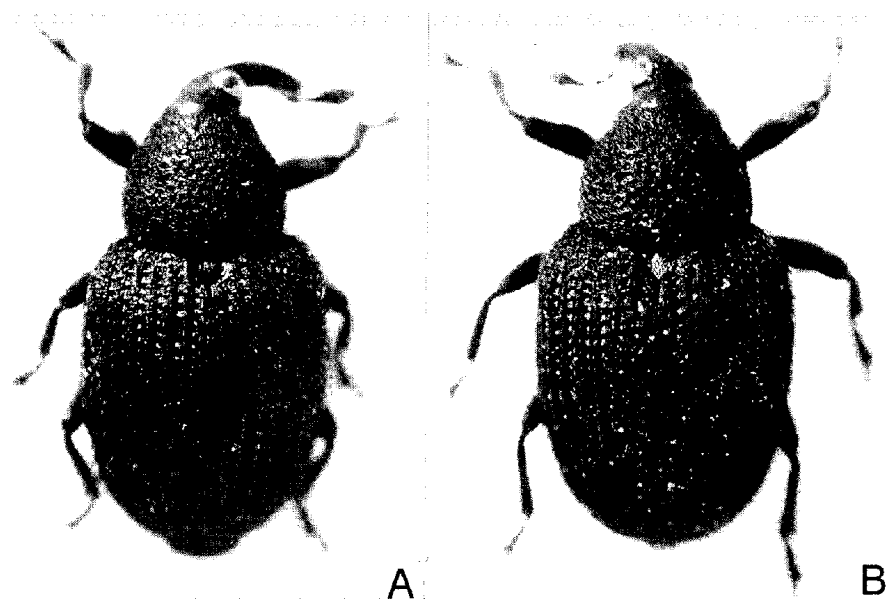

Fig. 10. Gryporrhynchus spp. A: senohi sp. nov. B: constricticeps sp. nov. 


\section{Gryporrhynchus senohi sp. nov.}

(Figs. 10B, 11E-F)

Male. Derm black, antennae and legs dark brown, unci of tibiae and tarsal claws brownish.

Head slightly constricted behind eyes; forehead between eyes $3 / 5$ times as wide as base of rostrum. Eyes weakly convex from temples. Rostrum a little shorter than pronotum, confluently punctured, with five rows of carinae behind antennal insertions, punctures becoming sparser before antennal insertions; antennal scrobe running to lower part of eye. Antennae inserted just a little before middle of rostrum, extending to apical one-third; scape longer than funicle $(3: 2)$; funicle with first segment more than twice as long as second, third and fourth subequal in length, a little shorter than second, fifth and sixth subequal in length, nearly as long as second; club as long as funicle.

Prothorax 1.3 times as wide as long, widest behind the middle, weakly rounded laterally, slightly constricted at apex; dorsum clothed with fine recumbent dark brownish setae, strongly punctured, each puncture with a subrecumbent dark stouter seta. Scutellum longer than wide, covered with recumbent setae. Elytra 1.15 times as long as wide, subparallel-sided at basal half; each interval clothed with fine recumbent dark

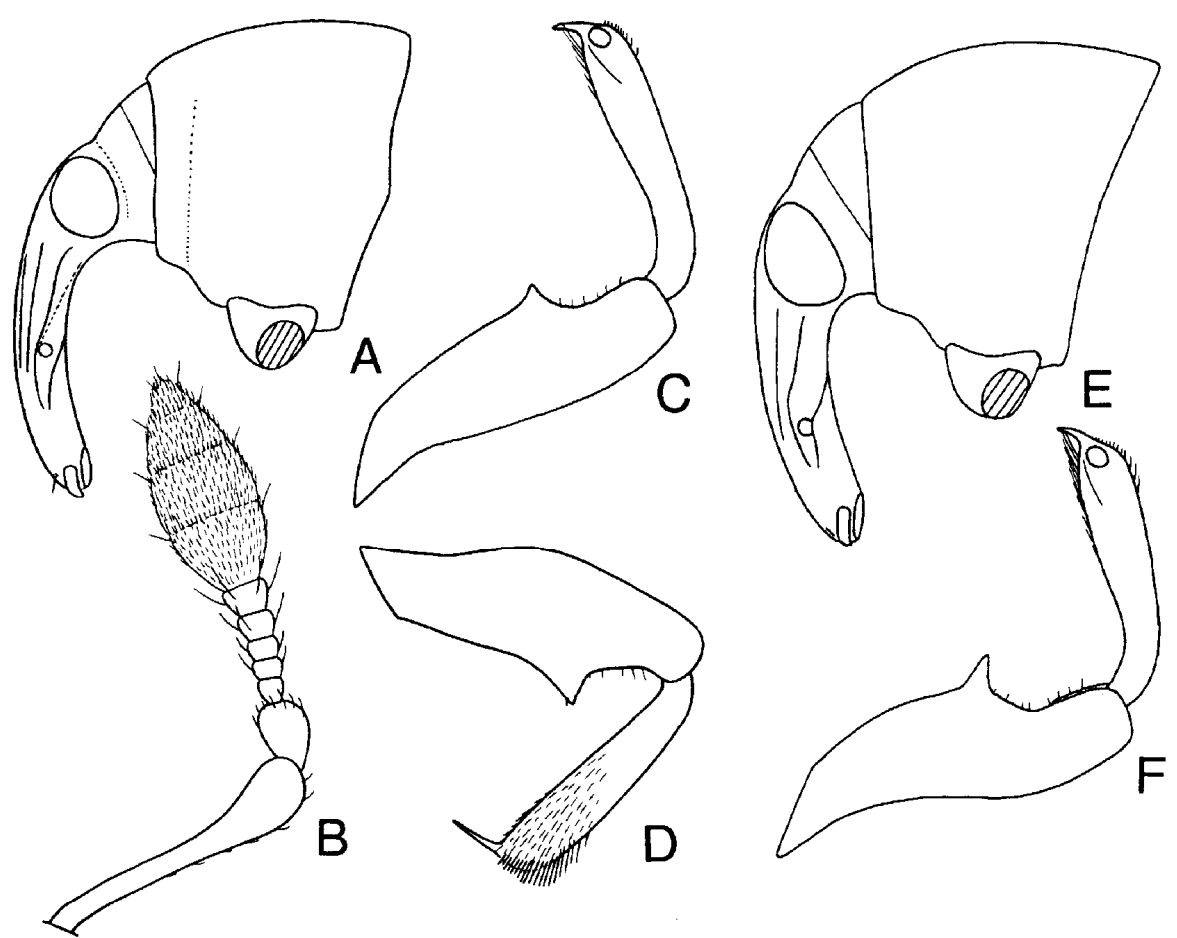

Fig. 11. A-D: Gryporrhynchus constricticeps sp. nov A, E: Head and prothorax, lateral. B: Antenna.

E, F: G. scnohi sp. nov. C, F: Front leg. D: Hind leg 
brownish setae, and medially with a row of subrecumbent dark stouter setae. Pygidium exposed, nearly vertical, clothed with dark brown stouter setae, propygidium visible at apex. Legs clothed wtih recumbent pale setae; each femur with a sharp triangular tooth, with a few erect setae beyond it; tibiae slightly widening to apex; claws each with a broad flat basal process.

Prosternum with distance between coxa and submarginal sulcus as great as that between this sulcus and anterior margin.

Female. Unknown.

Length: $1.4 \mathrm{~mm}$.

Holotype: male (Type No. 3014, Kyushu Univ.), Phayao, Chiang Muan, Thailand, 11. vi. 1993, T. Senoh leg.

Remarks: This is closely related to G. constricticeps sp. nov., but separable from it by the small uncus of hind tibiae and the flat mesosternal process.

\section{REFERENCES}

Csiki, E. 1936 Coleopterorum Catalogus, 149: Rhynchophorinae, Cossoninae. s'Gravenhage

Kojima, H. and K. Morimoto 1995a Study on the tribe Ochyromerini (Coleoptera, Curculionidae) from East Asia I, Descriptions of new species of the genera Endaeus and Endaenidius. Esakia, (35): 63102

Kojima, H. and K. Morimoto 1995b Study on the tribe Ochyromerini (Coleoptera, Curculionidae) from East Asia II, Genus Imerodes Marshall. Esakia, (35): 103-112

Kojima, H. and K. Morimoto 1995c The tribe Ochyromerini (Coleoptera, Curculionidae) of Japan I. Genera with six segments in the funicle. Jpn. J. Ent., 63: 557-571

Kojima, H. and K. Morimoto 1995d The tribe Ochyromerini (Coleoptera, Curculionidae) of Japan III. Genera with seven segments in the funicle and key to genera. Jpn.J. Ent. (in press)

Morimoto, K. 1962 Key to families, subfamilies, tribes and genera of the superfamily Curculionoidea of Japan excluding Scolytidae, Platypodidae and Cossoninae. J.Fac.Agr., Kyushu Univ., 12: 21-66

Morimoto, K. 1984 Curculionidae, In "Coleoptera of Japan in Color IV", ed. by M. Hayashi, K. Morimoto and S. Kimoto. Hoikusha, Osaka, pp. 269-345

Morimoto, K. and C. E. Lee 1992 Curculionidae from Cheju Island, Korea, with descriptions of three new species (Insecta, Coleoptera). Esakia, (32): 1-18

Roelofs, W. 1875 Curculionides recueillis au Japon par M. G. Lewis (3). Ann. Soc. ent. Belg., 18: 149$193,3 \mathrm{pls}$

Winkler, A. 1932 Catalogus Coleopterorumregionis palaearcticae. Wien 